\title{
SPARE THE ROD AND SPOIL THE CHILD? CORPORAL PUNISHMENT IN SCHOOLS AROUND THE WORLD
}

\section{INTRODUCTION}

Some children mature into adults without ever feeling the pain of physical punishment, others are far too familiar with the bruises and stinging sensations from whips, canes, slaps, and paddles. Physical punishment not only occurs at home behind closed doors, but at school, a place where young minds learn to become a part of an educated, civilized society. Most people dealing with children perceive corporal punishment as either the way to successfully control children or as a last-resort measure. ${ }^{1}$ The main issue that should be considered "in relation to discipline is how the essential processes used can contribute to a high level of intelligent socialization and character development in children."

Educational systems across the world have been dealing with debates surrounding appropriate types of discipline for teachers and administrators. Arguments in favor of using corporal punishment to correct poor behavior emphasize the belief that fear and pain will promote good conduct by students. ${ }^{3}$ Arguments against corporal punishment, which are becoming more prevalent in today's society, focus on human dignity, emotional and psychological problems, and the effects upon the learning environment itself. ${ }^{4}$ One major argument against corporal punishment is the failure of school officials to protect children from violence in school; thus denying them their right to be free from all forms of physical or mental violence and the full enjoyment of their right to education..$^{5}$ The right to be free from violence is one of the basic human rights afforded to adults and is a right children should be granted. ${ }^{6}$

1. See University of Alabama - Birmingham, Department of Education, Corporal Punishment: Children in a Changing Society, at http://www.uab.edu/educ/corp.htm (last visited Sept. 2, 2002) [hereinafter Children in a Changing Society].

2. Id. at 3.

3. See Susan Bitensky, Spare the Rod, Embrace Human Rights: International Law's Mandate Against All Corporal Punishment of Children, 21 WHITTER L. REV. 147, 148 (1999). This article addresses the human rights issues surrounding corporal punishment. See id. One of these issues is that corporal punishment is intended to cause pain based on the premise that the discomfort will induce the child to alter bad behavior. See id. at 149.

4. See Human Rights Watch: Children's Rights (1999), at http://www.hrw.org/ wr2k/Crd.htm (last visited Nov. 12, 2001) [hereinafter Children's Rights].

5. See id.

6. See Adah Maurer, Paddles Away: A Psychological Study OF Physical PUNISHMENT IN SCHOOLS 133 (1981). The author concludes his work with a Charter of Children's Rights wherein he states:

All children born into this world shall be accorded a basic set of human rights.

Among these are the right to a welcome, to health, safety, food, physical comfort, 
For some children, violence is a regular part of their school day. Teachers use caning, slapping, and whipping "to maintain classroom discipline and to punish children for poor academic performance." Such children are at risk of being physically hurt and/or psychologically damaged by the use of physical punishment. ${ }^{8}$ In general, children are both physically weaker and psychologically more vulnerable than adults and, therefore, deserve a greater degree of protection." Nonetheless, many still hold "the belief that corporal punishment of children has an educative and instructive purpose, without which a child will not be able to learn."10

Numerous international and regional human rights institutions such as: the U.N. Committee on the Rights of the Child, the Convention against Torture and Other Cruel, Inhuman, or Degrading Treatment or Punishment, and the Universal Declaration of Human Rights, have declared that some or all forms of school corporal punishment violate the human rights of children. ${ }^{11}$ Many nations have either restricted or have placed an explicit ban on corporal punishment in their schools. ${ }^{12}$

Evidence of corporal punishment in schools is apparent from the beginning of formal education. Corporal punishment has traditionally been recognized as a way of controlling behavioral problems in the classroom, and until recently, was accepted in cultures all over the world. ${ }^{13}$ Currently,

personal care, education, equal protection of the law, freedom to be a child, a gradually increasing autonomy, and respect as a person without regard to race, Id. at 133 sex, or economic status of the parents.

Part three further states:

SAFETY: All children shall have the right to be protected against abuse whether physical, psychological or sexual, and against neglect, dangerous situations and brutalizing physical punishments at home and while under the care of others at Id. at 134 .

school, recreational facilities and in other institutions temporary or permanent.

7. See generally Human Rights Watch: Spare the Child, Corporal Punishment in Kenyan Schools (1999), at http://www.hrw.org/reports/1999/kenya/index.htm [hereinafter Spare the Child], at pt. I. Summary, Kenyan law permits limited school corporal punishment. See id. Children are physically punished for a number of things from noise making to unsatisfactory academic performance. See id.

8. See Children in a Changing Society, supra note 1.

9. See Spare the Child, supra note 7, at pt. I. Summary.

10. Id. School corporal punishment can be a form of cruel, degrading treatment or punishment, and is akin to the use of beatings to punish detainees in prisons or police stations. See id. In such cases, state agents use violence to discipline and punish people under their supervision and control. See id. The violence is inflicted with the intention of causing physical pain and humiliation. See id. However, today corporal punishment of prisoners is accepted as a human rights violation. See id.

11. See infra Part V.

12. See Spare the Child, supra note 7, at pt. VII. Conclusion.

13. See Robert McCole Wilson, A Study of Attitudes Towards Corporal Punishment as an Educational Procedure From the Earliest Times to the Present (1971) (unpublished M.A. thesis, University of Victoria), available at http://www.socsci.kun.nl/ped/whp/histeduc/ 
physical punishment in schools is a controversial issue. Many international standards and regulations have expressly addressed the need to rid children of this type of degrading, inhuman treatment. ${ }^{14}$

This Note will discuss various issues involving the use of corporal punishment in school systems around the world. Part II discusses definitions of both corporal punishment and discipline, and discusses how they are understood by society. Part III examines the history and development of corporal punishment and looks at how the attitudes surrounding the use of corporal punishment have changed from being considered necessary to correct misbehaviors, to the belief that physical punishment serves no purpose in education. Part IV discusses international standards and regulations on the use of physical punishment of children. These standards pay particular attention to a child's right to human dignity and integrity. Part V addresses the rationales for inflicting physical punishment in schools. Part VI compares the effects the international standards and regulations have on nations. Part VII addresses the consequences of corporal punishment on children, both psychologically and behaviorally, now and in the future. Part VIII presents discipline alternatives to be used in the classroom and legal alternatives for schools all over the world to instill. Fortunately, other methods have been found to be as effective in modifying a child's behavior without the physical and mental harm of corporal punishment. Finally, part IX contains legal recommendations.

\section{DEFINITIONS}

In order to understand why there is a growing concern regarding corporal punishment, it is important to define the terms "corporal", "punishment," and "discipline." When broken down individually, the concern surrounding corporal punishment in the school environment becomes apparent.

\section{A. Corporal Punishment}

"Corporal" is defined as being of the body. ${ }^{15}$ The word "punishment", a form of the word "punish", is defined as imposing a penalty for an offense or fault. ${ }^{16}$ The term "corporal punishment" involves imposing a penalty for an offense or fault on a part of the body. While the definitions seem clear in

wilson/index.html (last visited Oct. 23, 2002) at pt. VII. Discussion. "[A]ttitudes towards and use of corporal punishment are an inseparable part of the beliefs and customs of society as a whole." Id.

14. See infra Part V.

15. See The American Heritage Dictionary 195 (3d ed. 1994).

16. See id. at 670. Punish also means to inflict a penalty for or to handle roughly or hurt. See id. 
that they refer to the intentional application of physical pain as a method of changing behavior, ${ }^{17}$ interpreting and applying the terms can be somewhat complex. This is due in part to the fact that what does and does not constitute a punishment, and the degree of such punishment, lies in the eyes of the beholder. Very often what is severe punishment to one may not be considered punishment by another.

Corporal punishment has also been defined as "the infliction of pain or confinement as a penalty for an offense committed by a student." ${ }^{18}$ In light of these definitions, corporal punishment can be carried out in ways other than direct assaults upon children's bodies. There is a mental aspect to the infliction of physical punishment that should not be distinguished from the physical aspects because there is always an emotional or mental component to physical punishment. ${ }^{19}$ Corporal punishment may be inflicted by the use of methods such as inflicting electrical shock, confining someone in closed spaces, forcing a student to assume painful bodily postures, or engage in excessive exercise drills. ${ }^{20}$

\section{B. Discipline}

As discussed above, corporal punishment by teachers is used as a disciplinary method to deter conduct that the teacher feels may inhibit learning. Discipline can be referred to as a type of training expected to produce a specific character or pattern of behavior. ${ }^{21}$ The degree to which the

17. See Society for Adolescent Medicine, Corporal Punishment in Schools: A Position Paper of the Society for Adolescent Medicine, 13 JOURNALOF ADOLESCENT HEALTH 240 (1992) [hereinafter Corporal Punishment in Schools], available at http://www.adolescenthealth.org/ $\mathrm{html}$ /corporal_punishment_in_schools.html (last visited Oct. 24, 2002). Corporal punishment encompasses a variety of methods including, but not limited to: hitting, slapping, punching, kicking, pinching, shaking, choking, use of various objects, painful body postures, use of electric shock, use of excessive exercise drills, or prevention of urine or stool elimination. See id.

18. IRWIN Hyman, Reading, WRITING, AND THE Hickory Stick 10 (1990). By definition, corporal punishment is not self-defense by teachers against attacks by students. See $i d$. Most corporal punishment is against students that are small and are not likely to strike back. See id. at 11.

19. See id. at 14. Experts are now recognizing that emotional reactions are the core of all physical punishment and/or abuse. See id.

20. See id. at 11. "Confinement for long periods has become increasingly popular...." $I d$. at 11. "Some educators have developed unreasonable and irrational variations on the theme of time-out." Id. at 12. Many children have experienced the equivalent of solitary confinement in jails. See id. "They have been locked in school safes, buried in boxes, and left in unventilated, stifling storerooms, and confined in all manners of uncomfortable boxes for periods lasting from days to weeks." Id.

21. See THE AMERICAN HeRtTAge Dictionary, supra note 15 , at 243. There are six meanings listed for the word discipline. See id. at 1 . Training expected to produce a specific character or pattern of behavior. See id. at 2 . Controlled behavior resulting from such training. See id. at 3. A state of order based on submission to rules and authority. See id. at 4. 
teacher maintains authority over the students is often looked at when determining the quality of a teacher's discipline. Student's behavior is also taken into consideration when speaking of the level of discipline within a particular classroom. ${ }^{22}$ Discipline may represent any measure serving as a deterrent to certain types of behavior perceived as negative.

\section{HISTORY}

No other issue has been such a continuing center of controversy in education as the use of corporal punishment in the classroom. For years, the rod, or its alternate, was the emblem of the teacher, and there was no doubt that punitive methods of social control worked in one way or another. Corporal punishment would not have been so widely practiced throughout human history if physical punishment had no effect on deterring poor behavior. Despite this practice and/or effect, few educators continue to support the use of physical punishment in the classroom and those that do have enacted regulations limiting its use. ${ }^{23}$

Practicing corporal punishment as a means of discipline in schools dates back to ancient times. ${ }^{24}$ For example, "the practice of physical punishment is related to the severity of the curriculum and atmosphere of schools in the early civilizations of Egypt and Babylonia."25

Furthermore, the use of corporal punishment in education also appears early in the recorded history of Western Judeo-Christian cultures. ${ }^{26}$ It has been noted that the Victorians attributed the expression "spare the rod and spoil the child" to Solomon, who is thought to be the author of Proverbs. ${ }^{27}$ In Christian theology, the use of corporal punishment is historically related to concepts of original sin and the need to combat Satan by "beating the devil" out of children. ${ }^{28}$

Punishment intended to correct or train. See id. at 5. A set of rules or methods. See id. at 6. A branch of knowledge or teaching. See id. The sixth definition does not pertain in the context discussed within.

22. See HYMAN, supra note 18 , at 137.

23. See WILSON supra note 13 , at 1 .

24. See Mary LeVine, Teachers' Attitudes TOWARds Corporal Punishment and ITS ALTERNATIVES IN THE SCHOOL ENVIRONMENT, 1 (1977).

25. Id.

26. See Ronald T. Hyman \& Charles H. Rathbone, Corporal Punishment in

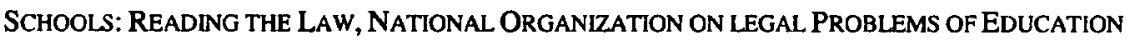
(1993). The use of corporal punishment has roots in the Old Testament. See id. quoting Proverbs 23:13-14 ("[w]ithhold not correction from the child: for it thou beatest him with the rod, he shall not die. Thou shalt beat him with the rod, and shall deliver him from hell") and Proverbs 22:15 ("[f]oolishness is bound in the heart of a child; but the rod of correction shall drive it from him."). Id. at 19.

27. HYMAN, supra note 18 , at 30 .

28. See id. at 31. In ancient and primitive cultures, it is thought that deviant behavior arises from being possessed by some sort of evil spirit. See id. 
The continued use of corporal punishment results from other factors as well. Until the past few decades, little research was done on the topic of corporal punishment. The majority of prominent figures in the history of education have had something to say, pro or con, about corporal punishment. But their comments have been based mostly on personal experiences and opinions. ${ }^{29}$ Due to the lack of research, people did not realize the long-term effects that physical punishment could have on a child. In addition, corporal punishment was the method of discipline for such a long time that educators were ignorant to, or ignored, the fact that other methods had an even greater potential of controlling classroom behavior. ${ }^{30}$

For thousands of years, societies accepted schoolteachers and administrators using the rod or its substitute as a method of deterring poor behavior. ${ }^{31}$ However, today few teachers and leaders support its use, and those who do, do so reluctantly. ${ }^{32}$ Teachers have been influenced by society to learn and develop non-physical methods of punishment and control in the classroom. ${ }^{33}$ One method that is becoming more and more popular is to encourage good behavior and instill consequences, such as time out or detention, for poor behavior rather than harsh punishments. ${ }^{34}$

\section{RATIONALE FOR INFLICTING CORPORAL PUNISHMENT IN SCHOOLS}

\section{A. Positive Attitudes Towards the use of Corporal Punishment}

For many, corporal punishment is viewed as an acceptable way of teaching children proper behavior. ${ }^{35}$ According to opinions favoring corporal punishment, children are better controlled, learn appropriate appreciation for authority, develop better social skills as well as improved moral character, and learn better discipline. ${ }^{36}$ The thought is that if corporal punishment is removed there will be greater disciplinary difficulty in the classroom. Likewise, due to current legal and popular opinions suggesting that it is

29. See WILSON supra note 13, at pt. 1.2 Previous Investigation. "Some mention is made of corporal punishment in most general histories of education, but usually only in passing." Id. citing LLUELA COLE, A HISTORY OF EDUCATION, SOCRATES TO MONTESSORI (1965); GERVAS D'OlbERT, ChASTISEMENT ACROSS THE AGES (1965); and GEORGE R. SCOTT, FlaGELLATION: A HISTORY OF CORPORAL PUNISHMENT (1968). Each author provides a brief history and a discussion on corporal punishment with a chapter on schools. See id.

30. See id.

31. See id. at pt. 1.1 A Continuing Controversy.

32. See id.

33. See infra Part VIII.

34. See infra Part VII.

35. See HyMAN \& RATHBONE, supra note 26 , at $18-19$. Some educators believe that corporal punishment teaches moral values and sets social expectations. See id. Corporal punishment "is swift and memorable, an immediate and palpable reminder, delivered on the spot and in terms that children will understand." Id. at 19.

36. See Corporal Punishment in Schools, supra note 17. 
acceptable for parents to physically punish their own children, it is also acceptable for teachers and educators to exercise this method because they serve as substitute parents during school hours. ${ }^{37}$

Much of the argument in favor of corporal punishment stems from the view that a good beating has historically proven to be an effective way of instilling obedience in the child, whereas less physical alternatives such as detention, suspension, and time out, have little effect as deterrents on student behavior. ${ }^{38}$ Some leading educational figures around the world still support the use of corporal punishment despite the fact that many nations have outlawed its use, believing that the fear of physical punishment may cause a child to work harder, and also that physical punishment does no harm unless it is overdone. ${ }^{39}$ Many advocates of corporal punishment realize that children can be physically hurt by this method and it should be "proportioned out in limited doses, based on the offense and without attempt to physically harm. ..."\$0

\section{B. Why Corporal Punishment Has No Place in Schools}

Corporal punishment of children fails to enhance moral character development, improve the teachers control in the classroom, or protect the teacher. ${ }^{41}$ Corporal punishment was previously used because it was so accessible that often teachers did not think about, or take the time to instill other means of disciplining or correcting behavior. ${ }^{42}$

The use of physical punishment in schools promotes a very dangerous message that violence is acceptable in society. ${ }^{43}$ Teachers have tremendous

37. See id.

38. See generally HYMAN, supra note 18.

39. See Julia Grey, MEC Fuels Debate About Corporal Punishment, THE TEACHER (March, 1999), available at http://www.teacher.co.za/9903/cane.html (last visited Oct. 23, 2002). The new head of education in KwaZulu-Natal, Eileen Shandu, is outspoken in her support for corporal punishment. See id. However, corporal punishment is in violation of the national constitution and the South African Schools Act. See id. Shandu states that if it were her way, corporal punishment would be reintroduced because it is an effective way of instilling obedience in the child. See id.

40. Corporal Punishment in Schools, supra note 17. Although corporal punishment is not supposed to physically harm the child, it must produce instant discomfort and must surprise the victim as soon as possible after the violation. See id.

41. See id. The society for Adolescent Medicine has concluded that corporal punishment is an ineffective method of discipline and has major effects on the physical and mental effects of children. See id. No clear evidence has been shown that physical punishment improves the culture of the classroom or teaches children proper behaviors. See id. See also C.S. Moelis, Banning Corporal Punishment: A crucial step toward preventing child abuse, 9 CHILD LEGAL RigHTS 2, 2-5 (1988).

42. See HYMAN, supra note 18 , at 190 . Teachers, especially those who are punitive, tend to move toward physical methods of discipline quickly and do not use a variety of alternatives. See id.

43. See Children in a Changing Society, supra note 1. 
power over the lives of children and are seen as role models of society. When educators resort to corporal punishment for misbehaving or failing to perform academically, an unhealthy norm is established. ${ }^{44}$ Children are encouraged to also resort to violent ways of solving unfavorable problems. ${ }^{45}$

Currently, End Physical Punishment of Children (EPOCH) is leading an international effort to make corporal punishment of children illegal. ${ }^{46}$ The goals of EPOCH are "to see changes in attitudes to children; to see children recognized as people - and [to recognize] that it is as wrong to hurt a child as it is to hurt another adult." ${ }^{47}$

According to EPOCH, there are many positive effects to ending corporal punishment in all settings, which include:

1. children can only achieve their full potential when they are recognized as individual people with rights of their own;

2. the current acceptance of physical punishment helps to cause more serious child abuse;

3. even 'light' physical punishment can unintentionally cause significant injuries to small children;

4. children who are hit by their parents learn that violent solutions are acceptable and are more likely in turn to hit their own children. Violence breeds violence. ${ }^{48}$

Corporal punishment and corrective discipline are not synonymous. As will be discussed later in this paper, there are other methods

44. See id.

45. See id. The result of using violent methods of punishment is that it teaches children that violence is especially acceptable against the weak, the defenseless, and the subordinate. See id.

46. See End Physical Punishment of Children, Hitting People is Wrong and Children are People Too, at http://www.neverhitachild.org/hitting.html (last visited Oct. 23, 2002).

47. Id.

48. Id. See also National Coalition to Abolish Corporal Punishment in Schools (NCACPS), Facts About Corporal Punishment, at http:// www.stophitting.com (last visited Aug. 3, 2002) [hereinafter Facts About Corporal Punishment] noting other arguments against corporal punishment including:

1. Corporal punishment perpetuates a cycle of child abuse. It teaches children to hit someone smaller and weaker when they are angry.

2. Physical injuries occur.

3. Educators and school administrators are often sued when corporal punishment is used in their schools.

4. Schools that use corporal punishment often have poorer academic achievement, pupil violence, and a higher dropout rate.

5. Corporal punishment is often used as a first resort.

6. Altematives to corporal punishment have proven to teach children to be self-disciplined rather than be cooperative out of fear.

See id. 
of correcting poor behavior in the classroom rather than resorting to whips, canes, and paddles.

\section{STANDARDS AND REGULATIONS ON HUMAN RIGHTS}

\section{A. U.N. Convention on the Rights of the Child}

The Convention on the Rights of the Child is the main international human rights instrument addressing the protection of children from violence and authoritatively prohibits the practice of corporal punishment in schools. ${ }^{49}$ Every country in the world, except for the United States and Somalia has, in upholding its protections for children, ratified the Convention on the Rights of the Child. ${ }^{50}$

Children's rights became a topic of international concern when the League of Nations adopted the first Declaration of the Rights of the Child in 1924 commonly called the Declaration of Geneva. ${ }^{51}$ The Convention on the

49. See Spare the Child, supra note 7, at pt. I. Summary.

50. Convention on the Rights of the Child, G.A. Res. 44/25, U.N. GAOR, 4th Sess., Supp. No. 49, U.N. Doc. A/Res/44/25 (1989) [hereinafter Convention]. The Convention was ratified without reservations by the following: Albania, Angola, Antigua and Barbuda, Armenia, Bahrain, Barbados, Belarus, Belgium, Belize, Benin, Bhutan, Bolivia, Bosnia and Herzegovina, Botswana, Brazil, Brunei Darussalam, Bulgaria, Burkina Faso, Burundi, Cambodia, Cameroon, Canada, Cape Verde, Central African Republic, Chad, Chile, China, Colombia, Comoros, Congo, Cook Islands, Costa Rica, Cote d'Ivoire, Croatia, Cuba, Cyprus, Czech Republic, Democratic People's Republic of Korea, Democratic Republic of the Congo, Denmark, Djibouti, Dominica, Dominican Republic, Ecuador, Egypt, El Salvador, Equatorial Guinea, Eritrea, Estonia, Ethiopia, Fiji, Finland, France, Gabon, Gambia, Georgia, Germany, Ghana, Greece, Grenada, Guatemala, Guinea, Guinea-Bissau, Guyana, Haiti, holy See, Honduras, Hungary, Iceland, India, Indonesia, Iran, Iraq, Ireland, Israel, Italy, Jamaica, Japan, Jordan, Kazakhstan, Kenya, Kiribati, Kuwait, Kyrgyzstan, Lao People's Democratic Republic, Latvia, Lebanon, Lesotho, Liberia, Libyan, Liechtenstein, Lithuania, Luxembourg, Madagascar, Malawi, Malaysia, Maldives, Mali, Malta, Marshall Islands, Mauritania, Mauritius, Mexico, Micronesia, Monaco, Mongolia, Morocco, Mozambique, Myanmar, Namibia, Nauru, Nepal, Netherlands, New Zealand, Nicaragua, Niger, Nigeria, Niue, Norway, Oman, Pakistan, Palau, Panama, Papua New Guinea, Paraguay, Peru, Philippines, Poland, Portugal, Qatar, Republic of Korea, Republic of Moldova, Romania, Russian Federation, Rwanda, Saint Kitts and Nevis, Saint Lucia, Saint Vincent and the Grenadines, Samoa, San Marino, Sao Tome and Principe, Saudi Arabia, Senegal, Seychelles, Sierra Leone, Singapore, Slovakia, Slovenia, Solomon Islands, South Africa, Spain, Sri Lanka, Sudan, Suriname, Swaziland, Sweden, Switzerland, Suriname Arab Republic, Tajikistan, Thailand, the former Yugoslav Republic of Macedonia, Togo, Tonga, Trinidad and Tobago, Tunisia, Turkey, Turkmenistan, Tuvalu, Uganda, Ukraine. Nations that have ratified the Convention with Declarations and Reservations: Afghanistan, Algeria, Andorra, Argentina, Australia, Austria, Bahamas, and Bangladesh. See id.

51. See Cynthia Cohen \& Susan Kilbourne, Jurisprudence of the Committee on the Rights of the Child, 19 MiCH. J. INT'L L. 633, 635-36 (1998). The Declaration of Geneva was concerned with child rights in terms of care and protection. See id. Paragraph 2 of the Declaration states that: "The child that is hungry should be fed; the child that is sick should be helped ... and the orphan and the homeless child should be sheltered and succoured." Id. quoting the 1924 Declaration of Geneva. 
Rights of the Child expanded the basic concepts of the Declaration of Geneva as the Convention continued to define children's rights in terms of protection and care.$^{52}$ Drafting the Convention began in 1979, under the support and help of a Working Group from the Commission on Human Rights, and it was completed ten years later. ${ }^{53}$ The Convention worked from concepts that were previously recognized, further developing them into a theory that "depicts the child as an individual with the right to have an opinion, to be a participant in decisions affecting his or her life, and to be respected for his or her human dignity." 54

"In 1999, the convention stood as the single most widely ratified treaty in existence." 55 Adopted by the United Nations General Assembly in 1989, the treaty includes a child's rights to: life, to be free from torture or cruel, inhuman, or degrading treatment or punishment; and on education. ${ }^{56}$ The Preamble recognizes that young children are entitled to special care and assistance and should be afforded the "inherent dignity and ... the equal and inalienable rights of all members of the human family ...."57 The drafters of the Convention make no reference to corporal punishment; however, the Committee read its prohibition into the language. ${ }^{58}$ The Committee stated categorically that all forms of corporal punishment are incompatible with the protections given to children under the Convention. ${ }^{59}$

Various Articles in the Convention address the safeguards of children, for example, Article 19(1) requires states to take:

all appropriate legislative, administrative, social and educational measures to protect the child from all forms of physical or mental violence, injury or abuse, neglect or negligent treatment, maltreatment or exploitation, including sexual abuse, while in the care of parent(s), legal guardian(s) or any other person who has the care of the child. ${ }^{60}$

52. See id. at 636.

53. See id. at 637. The Working Group used a model treaty given by the Polish government as a starting point to expand the concept of children's rights to one that not only is one of care and protection but one that protects a child's individual rights. See id.

54. Id. at 637-38.

55. Children's Rightś, supra note 4.

56. See id.

57. Convention, supra note 50 , at prmbl.

58. See Cohen, supra note 51, at 639-640.

59. See BARBRO HINDBERG, ENDING CORPORAL PUNISHMENT: SWEDISH EXPERIENCE OF EFForTS TO PREVENT ALL FORMS OF VIOLENCE AGAINST CHILDREN - AND THE RESUlts 8 (Swedish Ministry of Health and Social Affairs pamphlet, 2001).

60. Convention, supra note 50, art. 19. 
Article 28(2) states:

States parties shall take all appropriate measures to ensure that school discipline is administered in a manner consistent with the child's human dignity and in conformity with the present Convention. ${ }^{61}$

Article 37 states that children have a right to protection from "torture and other cruel, inhuman or degrading treatment or punishment." 37 of the Convention are used in various instances as a basis for criticizing countries that have not repudiated corporal punishment of children. ${ }^{63}$ In addition, the right to be free from corporal punishment is protected by the Convention's nondiscrimination principle, Article 2. Article 2 forbids justifying corporal punishment of children just because they are children. ${ }^{64}$ Also, in looking out for the best interests of the child, the Committee has advised that spanking is barred in Article 3, paragraph $1 .{ }^{65}$ Furthermore, under the Convention, states "must recognize the right of the child to "the highest attainable standard of health' and 'take all effective and appropriate measures with a view to abolishing traditional practices prejudicial to the health of

61. Id. art. 28(2).

62. Id. art. 37.

States Parties shall ensure that:

(a) No child shall be subjected to torture or other cruel, inhuman or degrading treatment or punishment. Neither capital punishment or life imprisonment without possibility of release shall be imposed for offenses committed by persons below eighteen years of age;

(b) No child shall be deprived of his or her liberty unlawfully or arbitrarily. The arrest, detention or imprisonment of a child shall be in conformity with the law and shall be used only as a measure of last resort and for the shortest appropriate period of time;

(c) Every child deprived of liberty shall be treated with humanity and respect for the inherent dignity of the human person, and in a manner which takes into account the needs of persons of his or her age. In particular, every child deprived of liberty shall be separated from adults unless it is considered in the child's best interest not to do so and shall have the right to maintain contact with his or her family through correspondence and visits, save in exceptional circumstances;

(d) Every child deprived of his or her liberty shall have the right to prompt access to legal and other appropriate assistance, as well as the right to challenge the legality of the deprivation of his or her liberty before a court or other competent, independent and impartial authority, and to prompt decision on any such action.

Id.

63. See HINDBERG, supra note 59, at 7.

64. See Bitensky, supra note 3, at 155.

65. See id. 
children." ${ }^{66}$ In reviewing these articles along with the Convention as a whole, it can be concluded that the acceptance of corporal punishment of children is not compatible with the Convention. The Committee strongly recommends prohibiting all corporal punishment, and suggests the establishment of campaigns to raise awareness of its negative effects. ${ }^{67}$

The Committee recommends legal reform in the area of juvenile justice administration be followed by taking into account the Convention on the Rights of the Child. ${ }^{68}$ "[A]ttention should be paid to the prevention of juvenile delinquency, the protection of the rights of children deprived of their liberty, respect for fundamental rights and legal safeguards in all aspects of the juvenile justice system and full independence and impartiality of the judiciary dealing with juveniles." ${ }^{169}$

The Committee decided to continue to dedicate attention to corporal punishment in 1993 by examining States Parties reports to demonstrate the importance of corporal punishment in improving the protection of child rights. ${ }^{70}$ The Committee on the Rights of the Child is now taking the lead to end violence inflicted upon children. ${ }^{71}$

\section{B. The Convention against Torture and Other Cruel, Inhuman, or Degrading Treatment or Punishment}

The Convention against Torture and Other Cruel, Inhuman or Degrading Treatment or Punishment (CAT) places limits on forms of discipline and punishment, including corporal punishment. ${ }^{72}$ The CAT promotes universal respect for human rights and fundamental freedoms, and provides that no one shall be subjected to torture or to cruel, inhuman or degrading treatment or punishment. ${ }^{73}$ The CAT also prohibits torture, which is defined as "any act 24.

66. HINDBERG, supra note 59 , at 7 , quoting Convention on the Rights of the Child, art.

67. See id. at 8.

68. Id.

69. Cohen, supra note 51 , at 646-647.

70. See HINDBERG, supra note 59, at 8.

The Committee's Guidelines for Periodic Reports ask "whether legislation (criminal and/or family law) includes a prohibition of all forms of physical and mental violence, including corporal punishment, deliberate humiliation, injury, abuse, neglect or exploitation, inter alia within the family, in foster and other forms of care and in public or private institutions, such as penal institutions and schools."

Id.

71. See id.

72. See Convention against Torture and Other Cruel, Inhuman or Degrading Treatment or Punishment, G.A. Res. 39/46 U.N. GAOR (1984). The ambition of the Convention is "to make more effective the struggle against torture and other cruel, inhuman or degrading treatment or punishment throughout the world ...." Id.

73. See id. 
by which severe pain or suffering, whether physical or mental, is intentionally inflicted on a person ...."74

"The Committee against Torture has indicated that corporal punishment is incompatible with the provisions of the Convention against Torture."7s Many committee members have expressed the view that it is "degrading treatment to apply corporal punishment in schools and other institutions." The Committee went on to say "[c]hildren should be treated with respect for their integrity and teachers should be able to maintain authority without resorting to such primitive measures."

\section{The Universal Declaration of Human Rights}

Corporal punishment has been recognized as a human rights issue for many reasons. First, corporal punishment is intended to cause pain as a way to control or modify a child's conduct. ${ }^{78}$ Secondly, corporal punishment is a human rights violation causing serious harm both during childhood and later in the victim's life. ${ }^{79}$

Many articles in the Universal Declaration of Human Rights are relevant to the discussion of the legality of corporal punishment in schools. ${ }^{80}$

\section{Id. art. 1(1):}

For the purposes of this Convention, the term "torture" means any act by which severe pain or suffering, whether physical or mental, is intentionally inflicted on a person for such purposes as obtaining from him or a third person information or a confession, punishing him for an act he or a third person has committed or is suspected of having committed, or intimidating or coercing him or a third person, or for any reason based on discrimination of any kind, when such pain or suffering is inflicted by or at the instigation of or with the consent or acquiescence of a public official or other person acting in an official capacity. It does not include pain or suffering arising only from, inherent in or incidental to lawful sanctions.

Id.

75. Spare the Child, supra note 7, at pt. III. Background.

76. Id. citing a discussion by the committee of human rights practices in Tanzania in its 1993 Annual Report. See id.

77. Id.

78. See Bitensky, supra note 3, at 147.

Corporal punishment is intended to cause pain based on the premise that the discomfort itself will induce the child to alter bad behavior. For the corporal punisher, pain is indispensable to correcting behavior. Torturers proceed upon the same assumption: pain is essential to intimidating the opposition. Such intentional infliction of pain is the very stuff of which human rights violations are made.

Id.

79. Id. at 149.

80. See Universal Declaration of Human Rights G.A. Res. 217A, (III), U.N. GAOR 3rd Sess., Doc. A/810 (1948) [hereinafter UDHR]. Articles 3 states, "[e]veryone has the right to life, liberty and security of person." Id. Article 5 states, "[n]o one shall be subjected to torture or to cruel, inhuman or degrading treatment or punishment." Id. 
According to the Human Rights Committee, corporal punishment is a form of cruel, inhuman, or degrading treatment protected by Article $7 .^{81}$ In a 1992 General Comment, the "committee reaffirmed its view that the prohibition 'must extend to corporal punishment, including excessive chastisement ordered as punishment for a crime or as an educative or disciplinary measure."

The principles encompassed in the Convention on the Rights of the Child and the Convention against Torture and Other Cruel, Inhuman, or Degrading Treatment or Punishment relating to corporal punishment are based on general human rights principles expressed in the Universal Declaration of Human Rights (UDHR). The UDHR recognizes the inherent dignity and equal and inalienable rights of all members of the human family as the foundation of freedom, justice, and peace in the world. ${ }^{83}$

\section{EFFECTS OF THE CONVENTION AND OTHER UNIVERSAL STANDARDS UPON NATIONS}

In ratifying the Convention on the Rights of the Child, the international community expressly recognized the need to protect children from the harmful effects of corporal punishment. ${ }^{84}$ Thus, it seems logical from a human rights perspective that children in schools should receive this same type of protection.

Various nations are taking positive steps towards restricting and even prohibiting corporal punishment. ${ }^{85}$ Some restrictions, through statutes and court decisions, ban corporal punishment in schools and in the home. ${ }^{86}$ Other restrictions take away common law immunity for educators who take part in the use of corporal punishment. ${ }^{87}$

Presently, "every European state, all but three industrialized nations (United States, Canada, and one state in Australia), and numerous other

81. See Spare the Child, supra note 7, at pt. III. Background.

82. See id. citing General Comments by the U.N. Human Rights Committee, U.N. Doc. A/37/40, annex V., paras. 1-3 (emphasis in original).

83. UDHR, supra note 80 , at pmbl. The General Assembly declares the Declaration as a standard of achievement for all nations whereby every individual and society shall strive by teaching and education to promote respect for all peoples in all nations. Id. at art. 26.

84. See Spare the Child, supra note 7, at pt. III. Background.

85. See id.

86. See id. All European and many African nations have statutes regarding corporal punishment. See id. The African Chanter on Human Rights contains provisions that "speak broadly to issues raised by corporal punishment in school." Id. at pt. III. Background. The European Convention for the Protection of Human Rights and Fundamental Freedoms also has a provision relevant to corporal punishment. See id.

87. See id. In some nations "corporal punishment is now considered similar to other forms of assault and battery." Id. 
countries around the world prohibit corporal punishment in schools." 88 The United States has not only denied ratification of the U.N. Convention on the Rights of the Child and continued to allow corporal punishment in schools, but has held that this type of punishment does not constitute cruel and unusual punishment under the Eighth Amendment ${ }^{89}$ to the U.S. Constitution. ${ }^{90}$

However, ratifying the Convention on the Rights of the Child does not mean that each nation has also explicitly banned the use of corporal punishment in schools. Many countries have taken portions of the Convention and implemented those parts into their own statutes and regulations that are tailored to their own culture or type of government. Germany was the ninth European country to pass legislation that banned physical punishment. ${ }^{91}$ For example, the Civil Code in Germany explicitly uses the term corporal punishment to eliminate any ambiguity by interpreters, stating "children have the right to a non-violent upbringing. Corporal punishment, psychological injuries and other humiliating measures are prohibited." ${ }^{92}$ Israel also placed explicit bans on physical punishment when Israel's National Council for the Child recognized "the right of children not to be exposed to violence of any kind, even when those who use violence ... [say it is] educational . . . .93 African governmental bodies have also taken into account child's rights. The African Charter on the Rights and Welfare of the Child prohibits harmful practices affecting the welfare, dignity, growth, and development of the

88. Id. See also Facts About Corporal Punishment, supra note 48. The following countries banned corporal punishment: Poland, 1783; Netherlands, 1820; Luxembourg, 1845; Italy, 1860; Belgium, 1867; Austria, 1870; France, 1881; Finland, 1890; Russia, 1917; Turkey, 1923; Norway, 1936; Japan, 1945; China, 1949; Portugal, 1950; Sweden, 1958; Denmark, 1967; Cyprus, 1967; Germany, 1970; Switzerland, 1970; Ireland, 1982; Greece, 1983; United Kingdom, 1986; New Zealand, 1990; Namibia, 1990; South Africa, 1996; England, 1998; American Samoa, 1998; Zimbabwe, 1999; Zambia, 2000; Thailand, 2000; Trinidad \& Tobago, 2000. Id.

89. See U.S. CONST. amend. VIII. "Excessive bail shall not be required, nor excessive fines imposed, nor cruel and unusual punishments inflicted." Id.

90. See Ingraham v. Wright, 430 U.S. 651, 683 (1977). The Supreme Court found that corporal punishment is permitted in the schools. See id. at 682 . However, public school teachers and administrators are privileged at common law to inflict only such corporal punishment as is reasonably necessary for the proper education and discipline of the child; any punishment going beyond the privilege may result in civil and criminal liability. See id. at 67678.

91. See Parenting Coalition International, International News: Global Progress Towards Ending All Corporal Punishment (2000), available at http://www.parentingcoalition.org/ stories/global_progress_towards_ending_a.htm (last visited Sept. 15, 2002) [hereinafter Parenting Coalition International].

92. Id.

93. Id. 
child. ${ }^{94}$ The Charter reaffirms adherence to the Convention on the Rights of the Child and the articles within parallel those found in the Convention. ${ }^{95}$

Bans on corporal punishment have been found in Japan and throughout countries in Africa and Europe. ${ }^{96}$ Australia does not have a universal law on corporal punishment but leaves the punishment issues for each jurisdiction to decide. $^{97}$ In some Australian States, the use of corporal punishment is completely banned, whereas in other States, moderate and reasonable corporal punishment can be lawfully administered for serious school offenses. ${ }^{98}$

The current status of corporal punishment can be looked at in three ways. First, there are the nations that have not only ratified the Convention on the Rights of the Child, but have also expressly banned the use of corporal punishment through statutes or judicial decisions. ${ }^{99}$ These nations include Sweden and Japan. ${ }^{100}$ Second, there are the nations that ratified the Convention on the Rights of the Child but have only placed restrictions on its use in schools, such as Kenya. ${ }^{101}$ And third, there is the United States which has neither ratified the Convention on the Rights of the Child nor placed a national ban on the use of corporal punishment in schools. ${ }^{102}$

94. See African Charter on the Rights and Welfare of the Child, Nov. 29, 1999, OAU Doc. CAB/LEG/24.9/49 (1990), at pmbl. [hereinafter African Charter].

95. Id. at pmbl.

96. See generally Parenting Coalition International, supra note 91.

97. See Australia's First Report under Article 44(1)(a) of the United Nations Convention on the Rights of the Child (1995) at para. 407, available at http://www/agdHome.nsf/Alldocs/ D91EE3EEA6D26578CA256B730014EC2d?Open Docu-ment (last visited Nov. 5, 2002) [hereinafter Australia's First Report].

98. See id. paras. 408-11. Article 44(1) of the Convention on the Rights of the Child states:

States Parties undertake to submit to the Committee, through the Secretary-General of the United Nations. reports on the measures they have adopted which give effect to the rights recognized herein and on the progress made on the enjoyment of those rights: (a) Within two years of the entry into force of the Convention for the State Party concerned ....

Convention, supra note 50. In upholding this obligation, Australia reported to the Convention that "torture and other cruel, inhuman, or degrading treatment or punishment," as stated in Article 37(a) of the Convention, "is not tolerated in Australia and constitutes a criminal and civil offense in all jurisdictions." See Australia's First Report supra note 97, para. 392. However; corporal punishment is only an offense if the particular Australian State considers it cruel, inhuman, or degrading. See id.

99. See Susan Bitensky, The United Nations Convention on the Rights of the Child and Corporal Punishment of Children: Ramifications for the United States, 5 GEO. J. ON FIGHTING POVERTY 225, 229 (1998).

100. See infra Part VI. A.

101. See generally Spare the Child, supra note 7.

102. See Allan Schwartz, Administration of Corporal Punishment in Public School System as Cruel and Unusual Punishment Under Eighth Amendment, 25 A.L.R. Fed. 431 (1975). 


\section{A. Explicit Bans on Corporal Punishment}

Explicit bans on corporal punishment are in place in nine European countries. ${ }^{103}$ The European Commission of Human Rights recognizes that the state bears the responsibility to ensure that children are not subjected to treatments that are contrary to the ban on degrading treatment or punishment while in school. ${ }^{104}$

One of the first countries to ban corporal punishment in schools was Sweden. ${ }^{105}$ One hundred years ago, corporal punishment was commonly used as the main method of classroom control in Swedish schools. ${ }^{106}$ There was a growing concern surrounding the fact that many pupils experienced severe beatings, which led to the Education Act being amended to forbid corporal punishment in secondary schools. ${ }^{107}$ The prohibition was not expanded to other schools until 1962, when it was applied to all levels of the school system. ${ }^{108}$

In 1966, there was a change in the Swedish Children and Parents Code so that it contained no wording justifying corporal punishment. ${ }^{109}$ However, because there was no provision expressly prohibiting corporal punishment, the Code was further amended in 1979. ${ }^{110}$ The section of the Children and Parents Code prohibiting corporal punishment reads as follows:

Children are entitled to care, security, and a good upbringing. Children are to be treated with respect for their person and individuality and may not be subjected to physical punishment or other injurious or humiliating treatment. ${ }^{11}$

The ban on corporal punishment is directed against treatment that endangers the child's personal development. ${ }^{12}$ The law forbids not only corporal punishment but mentally humiliating treatment as well. ${ }^{13}$ The concern

103. See Parenting Coalition International, supra note 91 . These countries include: Sweden (1979), Finland (1983), Norway (1987), Austria (1989), Cyprus (1994), Denmark (1997), Croatia (1999) Latvia (1998), and Germany (2000). See id.

104. See id. Other countries have also placed explicit bans on corporal punishment. See id.

105. See Joan E. Durrant, The Swedish Ban on Corporal Punishment: Its History and Effects, FAMILY VIOLENCE AGAINST CHILDREN: A CHALLENGE FOR SOCIETY (1996) excerpt, available at http://ww.nospank.net/durrant.htm (last visited Oct. 23, 2002).

106. See id.

107. See id.

108. See id.

109. See HINDBERG, supra note 59, at 12.

110. See id. at 11.

111. Durrant, supra note 105.

112. See id. The ban on corporal punishment not only forbids physical punishment but any mentally humiliating treatment as well. See id.

113. See id. 
regarding an increase in mental abuse when physical punishment decreased was addressed by the legislation. ${ }^{114}$

Despite the change in wording, the amendment carries no penalties for infractions of the ban. ${ }^{115}$ Punishments for violations remain within the Penal Code and are administrated only in instances satisfying the criteria for assault. ${ }^{16}$ The law was intended to alter public attitudes so children's rights as individuals would be recognized. ${ }^{117}$ So far, the law has prevailed.

Over the course of the past three decades, public attitudes have gone from a majority of Sweden's citizens supporting corporal punishment before the legislation to a few citizens supporting its use today. ${ }^{118}$ It has become a matter of community interest that children grow into socially competent and mentally strong individuals. A form of upbringing and education that suppresses and humiliates children cannot meet these interests. ${ }^{119}$ The ban on corporal punishment in Sweden granted children the fundamental human right to be free of physical violence both at home and in school, no matter how extreme the case of misbehavior. ${ }^{120}$

Laws against corporal punishment in Sweden have had a positive impact on reducing instances of corporal punishment. ${ }^{21}$ Not only is there an increasing amount of negative attitudes towards the use of corporal punishment, but there is also a correspondence between this attitude and its use. ${ }^{122}$ Occurrences of physical punishment have greatly decreased since the ban was enacted. ${ }^{123}$ However, this type of success has not been seen in all nations who have laws in place prohibiting corporal punishment.

In Japan, laws concerning corporal punishment have gone through many revisions. ${ }^{124}$ Currently, corporal punishment is still a problem in schools despite the fact that it is legally prohibited. ${ }^{125}$ Since school education began in Japan, corporal punishment was accepted and endorsed by teachers, parents, and students as an indispensable and effective way of teaching and

114. See id.

115. See Durrant, supra note 105.

116. See id.

117. See id.

118. See id.

119. See HINDBERG, supra note 59, at 12.

120. See id.

121. See id. at 15.

122. Id.

123. See Durrant, supra note 105. Recent studies have shown a decrease in the use of corporal punishment in the home and at school since the ban was enacted. See id.

124. Noboru Kobayashi, Corporal Punishment in the Schools and Homes of Japan, Child Research Net (1997), available at http://www.childresearch.net/CYBRARY/KOBY/ KORNER/CORPO.HTM (last visited Oct. 23, 2002). The first law banning corporal punishment was passed in 1879. See id. It was repealed in 1885 , reinstated in 1890 , repealed again in 1900 and reinstated in 1941. See id.

125. See id. 
learning. ${ }^{126}$ One teacher, angry about the mandate against corporal punishment stated " $[w]$ ithout corporal punishment ... there is no way to keep so many fun-loving, mischievous, disobedient, misbehaving, distracting students under control at school."127

Due to feelings similar to the teacher quoted above, corporal punishment continues to be a problem in Japan. ${ }^{128}$ The number of cases of corporal punishment reported from 1990 to 1995 was approximately 700 to 1,000 cases each year, and the number of schools using corporal punishment during the same period ranged from 600 to 850 per year. ${ }^{129}$ These figures show that during the five year period corporal punishment has been increasing in spite of the explicit ban.

The facts and examples discussed above illustrate while some nations have been successful in their ban on corporal punishment others have not. This may be due to the belief that some cultures have only known this type of punishment and are apprehensive in bringing about a change.

\section{B. Regulations on the Use of Corporal Punishment}

Very few nations who ratified the Convention on the Rights of the Child have implemented a complete ban on corporal punishment. ${ }^{130}$ Many nations, like Kenya, have enacted standards or regulations on its use.

"For most Kenyan children, violence is a regular part of the school experience." 131 The following story is just one instance of such infliction of pain. ${ }^{132}$ On September 23, 1998, Anastacia Katunge, thirteen years old, was severely caned by the headteacher at her school. ${ }^{133}$ Katunge reported that the teacher came to class and asked for a list of the noisemakers and after receiving the list, punished those students. ${ }^{134}$ The head teacher then called Katunge to the front of the class and started beating her. ${ }^{135}$ She was told to remove her cardigan and was then beaten with a cane more than five times on the back. ${ }^{136}$ At this point, she fainted and when she woke up she sat in her chair and waited for her classmates to go home. ${ }^{137}$ When she finally left, she

126. See Lee Chang-kook, [Ideas \& Ideals] Corporal Punishment (1999), at http://www.hankiikilbo.co.kr/14_8/199901/t4851.56.htm (last visited Sept. 16, 2002).

127. Id.

128. See Kobayashi, supra note 124.

129. See id. tbls. 2,3. There were about thirty to forty-five percent of teachers responsible for instances of physical punishment, hardly any were dismissed. See id. Of the schools using this type of punishment, twenty-five to eighty-five percent were legally sanctioned. See id.

130. See Bitensky, supra note 99, at 227-29.

131. Spare the Child, supra note 7, at pt. I. Summary.

132. See id.

133. Id.

134. See id.

135. See id.

136. See id.

137. Spare the Child, supra note 7, at pt. I. Summary. 
was bleeding from the neck and had bruises on her back that were bleeding as well. ${ }^{138}$

There are many cases similar to Katunge's in Kenya. However, her case was extraordinary due to her mother and father's initiative to report the incident. ${ }^{139}$ The headteacher in Katunge's case was ultimately charged with assault. ${ }^{140}$ Unfortunately, children who are physically disciplined at school either cannot make a formal complaint without dire consequences, or have parents that do not want to make a complaint. ${ }^{141}$

Many different forms of corporal punishment have a long history in Kenya. The Kenyan government school system began in the days of British colonial government, implementing nineteenth-century British traditions of school discipline, including the use of the cane. ${ }^{142}$ Most adult Kenyans were often caned as children and believe in the Biblical precept, "spare the rod and spoil the child." 143 According to a primary school headteacher, violence is "what the African child understands, and women too, they have to be beaten." 144

In some instances of corporal punishment in Kenyan schools, teachers use severe forms of corporal punishment out of sheer cruelty; however, a majority of teachers intend to "educate" children through canings and whippings. ${ }^{145}$ Parents and other members of society usually see nothing wrong with physical punishment based on the theory that the child will only learn after a good beating. ${ }^{146}$ Often, teachers justify serious injuries by arguing that the children only suffered physical injury because they were protecting themselves from the cane or whip. ${ }^{147}$ These events are usually seen as unfortunate and unavoidable. ${ }^{148}$ When a child is injured and attempts to press charges on the teacher or administrator, the severity of the charge depends on whether the doctor who examines the child classifies the injury as

138. See id.

139. Id.

140. Id. "Those who protest ill treatment are often forced to leave school altogether," loosing any chance for an education. Id.

141. See id.

142. See id.

143. Spare the Child, supra note 7, at pt. I. Summary.

144. Id. High levels of violence against children and women are a constant concem for Kenyan rights groups, and corporal punishment is included in this context. See id.

145. Id. Many hold the belief that corporal punishment of children has an educative and instructive purpose, without which a child will not be able to learn. See id.

146. See id.

147. See id.

148. See id. "To the extent that children are seriously injured, many Kenyans are willing to write such incidents off as tragic exceptions in a generally acceptable system." Id. 
"harm" or "grievous harm."149 Misdemeanor offenses arise out of assaults resulting in "harm" and felonies are assaults that result in "grievous harm."150

Kenyan law allows limited forms of corporal punishment, but only under highly restricted conditions. ${ }^{151}$ The 1972 Education (School Discipline) Regulations state that corporal punishment may only be administered under certain circumstances. ${ }^{152}$ These regulations permit the use of corporal punishment; however, the Minister of Education, Stephen Kalonzo Musyoka, informed Human Rights Watch that the Ministry discourages the use of the cane. ${ }^{153}$

While the Ministry claims the use of canes is discouraged, caning is the most preferred method of corporal punishment in Kenya. ${ }^{154}$ According to these regulations, corporal punishment is reserved for certain behaviors and can only be administered after a full inquiry by the headteacher, and in the presence of a witness other than another pupil. ${ }^{155}$ The regulations further state the headteacher may inflict no more than six strokes and must keep a written record of each incidence. ${ }^{156}$ These regulations, if followed, seem to take control of such a controversial issue. However, a report by Human Rights Watch found every classroom teacher has the independent authority to cane students. ${ }^{157}$ One of the headteachers interviewed for the report implied the regulations were impractical and said "[d]iscipline is supposed to be done by

149. Spare the Child, supra note 7, at pt. IV. Corporal Punishment in Kenyan Schools. "[H]arm means any bodily hurt, ... whether permanent or temporary ..., [and] grievous harm means any harm which amounts to main, or endangers life or seriously or permanently injures health, or which is likely so to impair health, or which extends to permanent disfigurement ...." Id.

150. See id.

151. See id.

152. See id. at pt. III. Background. The Education (School Discipline) Regulations, The Laws of Kenya, chapter 21, article 1; corporal punishment may be "inflicted in cases of continued or grave neglect of work, lying, bullying, gross insubordination, indecency, truancy or the like." Id. Article 12(1) and 12(2) state that corporal punishment may only be imposed by or in the presence of the school's head teacher or principal; and, "it may be inflicted only after a full inquiry, and not in the presence of other pupils ...." Id. Article 14 finds that records must be kept of all cases of corporal punishment. See id.

153. See id. quoting Interview by Human Rights Watch with Stephen Kalonzo Musyoka, M.P., Minister of Education, Nairobi, Kenya (May 5, 1999).

154. See generally Spare the Child, supra note 7, at pt. IV. Corporal Punishment in Kenyan Schools. Research conducted by Human Rights Watch indicates that caning is imposed regularly, and administered in a way inconsistent with the regulations. See id. Almost every teacher has a cane that is accessible in the classroom. See id.

155. See id.

156. See id. Despite these regulations, the number of strokes a student receives usually depends on many factors, such as expression of pain by the child, poor exam results where the number of strokes depends on the performance, or excessive noise making. See id. More than one teacher also canes some children at a time. See id.

157. See id. 
the headmaster but he can't because there are so many students, so he delegates his authority to junior teachers who do it."158

Many factors determine the type of physical punishment a student will receive. These factors include the harshness of the teacher, the school, and the nature of the misconduct. A particular student might receive anywhere from two to twenty strokes of the cane at a time. ${ }^{159}$ The reported frequency of caning also varies from school to school and ranges from one or more canings a day at most schools, to one caning a week or even one a month. ${ }^{160}$ Canings occur for a wide range of behavioral violations, some serious and some very minor. Children may receive corporal punishment for being tardy, having a dirty or torn uniform, rudeness, fighting, and any form of disruptive classroom behavior. ${ }^{161}$ Children are frequently caned for poor academic performance, failure to complete homework assignments or learn lessons, and other circumstances not within the student's control. ${ }^{162}$

Another regulation set by the Ministry of Education but often not followed involves conducting full inquires with the child and keeping records of each instance. ${ }^{163}$ In interviews with children, Human Rights Watch found that teachers often caned students without waiting for an explanation of the perceived misbehavior, and few punishments were actually recorded. ${ }^{164}$

In light of the report from Human Rights Watch, it seems as though the Ministry of Education has not been persistent in enforcing the provisions of the Education (School Discipline) Regulations, which limit the use of corporal punishment. ${ }^{165}$ Government responses to serious incidents of corporal punishment have been inadequate to combat such abuse. ${ }^{166}$ When children are injured, the school may offer to pay medical expenses, but teachers are rarely dismissed, prosecuted, or even disciplined. ${ }^{167}$ Headteachers and teachers who

158. Id.

159. See Spare the Child, supra note 7, at pt. IV. Corporal Punishment in Kenyan Schools.

160. See id.

161. See id. Other grounds for physical punishment include, graffiti, stealing, missing school, not paying attention, giving wrong answers, failure to pay fees, and many others. See id.

162. See id. Children may not have the appropriate books to do their assignments, or their parents may not have enough money to pay for a proper uniform. See id.

163. See id.

164. See id. Interviews with children showed that caning was more frequent than the logbooks of the schools demonstrate. See id.

165. See generally, Spare the Child, supra note 7, at pt. IV. Corporal Punishment in Kenyan Schools.

166. See id.

167. See id. Some parents have pressed charges but in almost every case teachers have been acquitted, or when teachers have been convicted, they have been handed extremely light sentences such as minimal fines. Id. 
cane children may be criminally prosecuted for assault; however, difficulties arise that prevent or reduce liability. ${ }^{168}$

Kenya's Education Minister said the government would implement a new policy officially banning corporal punishment in late 2000 ${ }^{169}$ However, as of this writing, there are no reports that this has occurred. So far, enforcing the regulations has not been successful, but if a complete ban is recognized, there will be no excuse as to why regulations were violated or physical punishment was inflicted. Eliminating regulations would remove subjective judgments on how serious the misbehavior is and whether the punishment was excessive.

\section{United States}

In the United States, corporal punishment has been the conventional method for disciplining children since colonial times. ${ }^{170}$ However during the past two decades, there has emerged a growing protest condemning physical punishment of children. ${ }^{171}$

"In 1972, the American Civil Liberties Union (ACLU) .. . sponsored a formal conference on [the subject of corporal punishment]. At that time, only two states (Massachusetts and New Jersey[)] legally banned corporal punishment in schools." 172 "In 1974, the American Psychological Association passed a formal resolution banning corporal punishment in schools and established the Task Force on Children's Rights . . .."173 In 1987, the National Coalition to Abolish Corporal Punishment in Schools was developed and united in their efforts to ban the physical punishment of children in school. ${ }^{174}$

168. See id. Kenya's Evidence Act prohibits anyone from being convicted of a crime based solely on the testimony of a young child. See id. It has also been noted that police and education officials typically try to handle cases administratively and avoid the legal system altogether. See id. Furthermore, the Teacher Services Commission has the responsibility of disciplining government-employed teachers and does not undertake investigations of corporal punishment unless complaints are brought to it despite the widespread media coverage of injuries resulting from school physical punishment. See id. at 12.

169. See Parenting Coalition International, supra note 91.

170. See Corporal Punishment in Schools, supra note 17.

171. See id.

172. Id.

173. Id. Also, the National Education Association published a report in the 1970's that denounced corporal punishment in schools and recommended it be abolished. See id.

174. See id. Included in the coalition was the National Center on Child Abuse Prevention, the American Academy of Pediatrics, the American Bar Association, the American Medical Association, the Parent-Teacher's Association, the National Education Association, and the Society for Adolescent Medicine, along with over twenty other groups interested in abolishing the practice of physically punishing children in school. See id. at 2 . This coalition still has an active movement with national and local meetings along with publications and various other avenues for cultivating public awareness regarding physical punishment of children. See id. 
In 1867, New Jersey became the first state in the United States to ban corporal punishment of discipline in schools. ${ }^{175}$ As of 1990, twenty-seven states had banned corporal punishment in schools, ${ }^{176}$ and even in states where it was legal, many school districts enacted policies prohibiting it. ${ }^{177}$ At that time, out of the twenty-three states that continued to allow corporal punishment, Mississippi had the highest percentage of students struck by educators. ${ }^{178}$

A popular opinion in the United States is that applying physical punishment to children at school is legally permissible. ${ }^{179}$ Since before the American Revolution, the common law has provided that a teacher may use reasonable force in disciplining children but any excessive force will lead to liability for personal injuries. ${ }^{180}$ However, the legality of corporal punishment has recently been questioned from different perspectives. ${ }^{181}$ Some arguments include:

(1) the social and psychological arguments that society has progressed past the physical punishment stage; (2) the idea that legally corporal punishment is "cruel and unusual punishment" as prohibited by the Eighth Amendment, and (3) that corporal punishment should not be administered without first providing the student with procedural due process of law as prescribed in the Fourteenth Amendment. ${ }^{182}$

In considering these perspectives, physical punishment in the United States is not deemed to be so "excessive" or "degrading" in the constitutional

175. See Corporal Punishment in Schools, supra note 17.

176. See Facts About Corporal Punishment, supra note 48. The following states have banned corporal punishment by state regulation: New Hampshire, New York, and Utah. Id. In Rhode Island, every school board in the state has banned corporal punishment, and in South Dakota corporal punishment has been banned by law rescinding authorization to use this method of punishment. See id. The following states have also banned corporal punishment in school: Alaska, California, Connecticut, Hawaii, Illinois, Iowa, Maine, Maryland, Massachusetts, Michigan, Minnesota, Montana, Nebraska, Nevada, New Jersey, North Dakota, Oregon, Vermont, Virginia, Washington, West Virginia, and Wisconsin. See id.

177. See HYMAN, supra note 18, at 228-29. Local efforts are winning individual school districts in: Colorado, Kansas, Arizona, Louisiana, New Mexico, Wyoming, Delaware, Missouri, Texas, South Dakota, Arkansas and Florida. See id.

178. See Facts About Corporal Punishment, supra note 48. According to the U.S. Department of Education, Office for Civil Rights, 1998 Elementary and Secondary School Civil Rights Compliance Report, the following states rank in the list of top ten worst for the issuance of corporal punishment: Mississippi is the worst at $10.1 \%$ followed by Arkansas $9.2 \%$, Alabama 6.3\%, Tennessee 4\%, Oklahoma 3\%, Louisiana 2.7\%, Georgia 2.13\%, Texas $2.07 \%$ Missouri $1.1 \%$ and New Mexico .9\%. See id.

179. See Corporal Punishment in Schools, supra note 17.

180. See id.

181. See KeRn Alexander, SCHOOl LAW 8 (1980).

182. Id. at 320. 
sense as to violate the "cruel and unusual punishment clause" of the Eighth Amendment. ${ }^{183}$ In 1977, the Supreme Court held in Ingraham v. Wright ${ }^{184}$ that moderate corporal punishment does not violate the constitutional prohibition against cruel and unusual punishment contained in the Eighth Amendment, or the guarantee of liberty contained in the Fourteenth Amendment. ${ }^{185}$ According to the court, the proscription against cruel and unusual punishment is designed to protect those charged or convicted of a crime and not students in a disciplinary setting. ${ }^{186}$ However, physical punishment may be found to be cruel and unusual where the incident has caused severe physical harm. Whether an incident of corporal punishment in the school is considered cruel and unusual under the Constitution depends mainly on the circumstances and setting at the time and not on the manner of punishment. ${ }^{187}$

In Ingraham, the court "left open the question of whether and under what circumstances corporal punishment of a student might give rise to an independent federal cause of action to vindicate substantive rights under the due process clause." 188 In 1975, the United States Supreme Court determined "that the due process provisions of the Fourteenth Amendment require that students are entitled to a hearing prior to any prolonged ejection from school for disciplinary reasons." 189 However, the Ingraham court found that common law remedies, civil actions, and criminal liability adequately protected due process rights of students. ${ }^{190}$ Different circuit courts have tried to answer the question left by the court in Ingraham but "[n]evertheless, the burden of establishing a substantive due process violation, regardless of which circuit's definition is used, is a very difficult burden to meet."191

From district to district, legislature to legislature, corporal punishment policies are changing. ${ }^{192}$ For people interested in furthering change in corporal punishment policy, federal courts are reluctant to institute such a

183. See Schwartz, supra note 102 , at 433 .

184. See Ingraham, 430 U.S. at 656-658. James Ingraham brought suit arguing that his Eighth Amendment rights to be free from cruel and unusual punishment had been violated after being paddled less than twenty times with a wooden paddle two feet in length, three to four inches wide and one-half inch thick. See id.

185. See Eve CAREY ET AL., AMERICAN CIVIL LIBERTIES UNION: THE RIGHTS OFSTUdENTS 107-111 (1997). See also Ingraham, 430 U.S. The decision in Ingraham is stunning because it left us with the fact that public schools are the only governmental-run institutions where corporal punishment is allowed. See id. Corporal punishment has been banned in places such as the military services and prisons. See id. It does not make sense that the government allows the physical punishment of school children if they cannot hit prisoners. See id.

186. See Ingraham, 430 U.S. at $654-58$.

187. See Schwartz, supra note 102, at 433.

188. Corporal Punishment in Schools, supra note 17. See also Ingraham, 430 U.S.

189. Corporal Punishment in Schools, supra note 17. See also Goss v. Lopez, 419 U.S. 565 (1975).

190. See Ingraham, 430 U.S. at 667-68.

191. Corporal Punishment in Schools, supra note 17.

192. See Hyman \& RathBONE, supra note 26 , at 25. 
change. ${ }^{193}$ Many believe there is probably little chance of national legislation or a Supreme Court decision that will abolish corporal punishment in schools. ${ }^{194}$ Therefore, there is little doubt that the best way to eliminate corporal punishment in schools is through a "state-by-state assault." 195

However, if the United States were to pass a statue banning corporal punishment, it would need to be one that was both familiar and accessible to the average citizen. ${ }^{196}$ A possible version of a statute expressly banning physical means of punishment and also containing penalty language that an offender could be prosecuted under may read as follows:

(1) (a) Corporal punishment is defined as the use of physical force with the intention of causing a child to experience bodily pain so as to correct, control, or punish the child's behavior.

(b) Any person who uses corporal punishment on a child shall be guilty of the crime of battery provided that such physical force would be a battery if used on an adult.

(2) The penalties for conviction pursuant to subsection (1) shall be the same as those for conviction under any other criminal battery provisions or, in lieu thereof in appropriate cases, shall be a post-trial or post-plea diversion program.

(3) Nothing stated in subsections (1) or (2) herein shall preclude or limit further prosecution under any other applicable laws for the use of corporal punishment described in subsection (1).

(4) The proscription set forth in subsection (1) shall not apply to the use of such physical force as is reasonably necessary to prevent death or imminent bodily pain or injury to the child or others. ${ }^{197}$

193. Id.

194. See HYMAN, supra note 18, at 220.

195. Id. at 213-20. Political action is a great way to change policy in the United States. See id. at 215 . A number of state professional organizations that are backed by national policy are against the use of corporal punishment in schools. See id.

196. Bitensky, supra note 99, at 231. The United States has a legal system that does not make laws to "merely to announce preferred policies without creating adjunctive enforceable rights, duties, or liabilities." Id.

197. Id. at 231. Subsection one defines corporal punishment and distinguishes prosecutable conduct from acts that may cause pain for another reason, and requires that prosecutable use of force must be for the purpose of correcting, controlling, or punishing the child's behavior. See id. Subsection two then makes the penalties for hitting a child the same as those for hitting an adult to portray that children are worthy of the same protection. See id. 
Widespread enactment of this type of statute may not fit into the national legal scheme, but each state could enact a similar statute to rid society of the physical punishment of children in schools.

\section{CONSEQUENCES OF CORPORAL PUNISHMENT IN SCHOOLS}

School serves as a model of society and is an indicator of the values and policies of its citizens. Sometimes the school leads by furthering educational goals, sometimes it follows the changing needs of the community, and many times it does both. This leads to the perception that corporal punishment is symbolical of the culture in which it lies. Both proponents and opponents of corporal punishment see the effect as being long lasting and having a great impact outside the school day or school calendar. ${ }^{198}$

\section{A. PSYCHOLOGICAL EFFECTS}

Psychological abuse can take many forms, including exposing children to institutional practices that deny the opportunity for the maintenance of basic human needs. Five conditions have been associated with psychological maltreatment:

1. Discipline and control techniques based on fear and intimidation[;]

2. Low quantity and quality of human interaction in which teachers communicate a lack of interest, caring, and affection for students[;]

3. Limited opportunities for students to develop competencies and feelings of self-worth, especially for children who lack ability or motivation for high-level academic work[;]

4. Encouragement to be dependent and subservient, especially in areas where students are capable of making independent judgments[;]

5. Denial of opportunities for healthy risk taking such as exploring ideas that are not conventional and approved by the teacher. ${ }^{199}$

198. See HYMAN \& RATHBONE, supra note 26, at 19-21. Those concerned about violence in society see corporal punishment as a dangerous contribution to that violence. See id. Those concerned about the breakdown of the social order see corporal punishment as an important means of controlling undisciplined behaviors that lead to a disorderly classroom. See id.

199. See HYMAN, supra note 18, at 15 citing Stuart Hart, Psychological Maltreatment in Schooling, SCHOOL PSYCHOLOGY REVIEW 16(2) (1987). 
A loss of confidence may be caused by self-depreciating actions and statements made by the teacher. ${ }^{200}$ For example, when a child tries to explore new ideas and express his or herself in creative ways, but is physically and mentally demeaned in front of his or her peers, the child's sense of self worth is greatly reduced. ${ }^{201}$ Low self-esteem can start a vicious cycle of academic deficiency, rebellion, and removal from any interactions with educators and peers. ${ }^{202}$

Traumatic and unforgettable experiences can arise out of caning and whipping young children. Many educators believe that corporal punishment will more likely cause a child to fear school, which undermines the entire purpose of education. ${ }^{203}$ Experts have found corporal punishment produces in children neurotic reactions, such as depression, withdrawal, anxiety, tension, and in older children, substance abuse, and interference with school work. ${ }^{204}$ Especially when children are caned or whipped in front of their classmates, they feel humiliated and degraded, and end up resenting those who punish them. ${ }^{205}$

Physically reprimanding children does not model desirable behavior unless society wants children to become violent and aggressive. Psychological and educational research indicates that children who are physically punished themselves are more likely to bully their peers. ${ }^{206}$ To a considerable extent, children learn by imitating the behavior of adults, especially those with whom they interact and depend on daily. Therefore, the use of corporal punishment by adults having authority over children will likely lead children to use physical violence to control the behavior of others rather than a rational, educational, and intelligent form of positive and negative reinforcement. ${ }^{207}$

\section{B. Effects on Class Discipline}

Teachers do not need a cane to teach discipline in the classroom. According to many experts,

200. See id. at 20.

201. See id.

202. See Corporal Punishment in Schools, supra note 17.

203. See Corporal Punishment Should be Abolished in Schools, THE GuARDIAN, Dec. 14, 1999, available at http://www.newafrica.com/education/articles/caning.htm (last visited Oct. $24,2002)$. When a child goes to school with the fear of being caned, his or her learning is weighed down with psychological problems that may affect the child all throughout life. See id.

204. Bitensky, supra note 3, at 150.

205. See id.

206. See Adah Maurer, Paddles Away: A Psychological Study of Physical PUNISHMENT IN SCHOOLS 25 (1981).

207. See id. at 26. Physical punishment, unless neutralized by other favorable circumstances, injects a streak of cruelty into the character of the victim. Id. at 25 . 
there is considerable data indicating that corporal punishment does not, in any consistent way, deter misbehavior or encourage good behavior on the part of children. Most experts agree that corporal punishment does nothing to fulfill the disciplinary goal of developing a child's conscience so as to enable him or her to behave well .... . ${ }^{208}$

When teachers inflict physical punishment upon students, it does not teach them what they did wrong, rather it illustrates the fact that the teacher deemed the behavior undesirable. This is due in part to the fact that corporal punishment is a general method of discipline that is directed at all types of misbehavior. It can become very confusing for children when the punishment is always of a physical means whether they were misbehaving or failing to perform well academically. Without understanding what about their behavior was inappropriate, the behavior cannot be corrected; the cycle continues, thus never reaching the goals of education. Poor behavior is not defeated by a cane or whip. Children are individual human beings with needs that do not include infliction of pain.

\section{ALTERNATIVES TO CORPORAL PUNISHMENT}

Corporal punishment is a method of behavioral and intellectual control that many generations have grown up knowing. For the teacher, it is easily accessible and serves the instant purpose of making the child aware of their misbehavior. Physical punishment instills a sense of control and order that most think is necessary for a successful learning environment. However, other forms of behavior management can be just as successful without the painful, harsh, long-term effects. These forms include: (1) the use of positive reinforcement and (2) the incorporation of the term 'consequences' rather than punishment. For these methods to prevail, programs need to be instituted educating teachers on different ways of classroom management. There also needs to be support from society to work along with the schools in eliminating physical punishment of children. ${ }^{209}$

208. Spare the Child, supra note 7, at pt. V. Corporal Punishment's Impact, citing Susan Bitensky, Spare the Rod, Embrace our Humanity: Toward a New Legal Regime Prohibiting Corporal Punishment of Children, 31 U. Mich. J.L. REF. 353, 426 (1998).

209. See Corporal Punishment in Schools, supra note 17. Teachers need to receive as much support and training as possible in their efforts to maintain classroom control without resorting to violence. See id. Teachers should receive information regarding the effects on physical punishment and have available to them classes concerning other methods of instilling control. See id. 


\section{A. Positive Reinforcement}

One important technique to maintaining classroom control is creating an environment that conveys a mutual sense of value and respect. ${ }^{210}$ Principles for learning behavior and misbehavior are based on reward and punishment tailored to particular students at particular times. Educational experts who oppose corporal punishment have found that positive reinforcement techniques have the tendency to reduce the frequency and extent of student misconduct. ${ }^{211}$ Positive reinforcement techniques in the classroom can be just as accessible as corporal punishment. Some examples include: verbal praise, a pat on the back, or extra free time for good behavior.

One problem with this type of technique is that some teachers are reluctant or simply do not believe that children should be reinforced for good behavior. ${ }^{212}$ These teachers look at reinforcement as bribery and think that children will take advantage of the classroom structure. ${ }^{213}$ However, one characteristic of a well-managed classroom is frequently reinforcing children for appropriate behavior. ${ }^{214}$ A way for this to happen is to provide a positive model of good behavior without calling attention to the bad behavior. ${ }^{215}$ Positive reinforcement does not mean taking away all forms of punishment, but when a child misbehaves, they should be able to explain what happened and the punisher should explain what they did, and why it was wrong.

\section{B. Consequences}

More and more educators and administrators are beginning to use the term "consequences" rather than punishment. Consequences can provide clear and definitive answers to children's active inquiries on what is and is not acceptable. ${ }^{216}$ Consequences can also teach children who is in charge and what their responsibilities are by holding children accountable for their choices and behavior. ${ }^{217}$

210. See id. School officials should exhibit cordiality to students and an attitude that they generally enjoy working with them and value their needs. See id.

211. See Spare the Child, supra note 7. There are many ways that positive reinforcement can be carried out. See id. For example, a teacher can praise students in front of other classmates and teachers, award special certificates to those who perform well or list their name on a blackboard. See id.

212. See HYMAN, supra note 18, at 137.

213. See id.

214. See id.

215. See id. at 138. Modeling can occur in the classroom when, for example, three children are sitting together and one is misbehaving, the teacher can merely say to the other two, "I appreciate you doing your work" without saying anything to the misbehaving child. Id.

216. See Robert J. MACKenZie, SETting Limits IN THE ClasSROOM 164 (Prima Publishing 1996).

217. See id. Consequences, when used consistently, define the path for students to stay on. See id. Consequences accomplish the goal of stopping misbehavior when it occurs. See id. 
What makes the consequences effective are the ways in which they are applied. If they are applied in a punitive or permissive manner, consequences will have limited value and teachers will find themselves reverting back to old methods that are easily accessible and provide quick effective results. On the other hand, if consequences are applied in a democratic manner, lessons and signals will be clearer. ${ }^{218}$ It may take a while for students to get used to the idea of consequences, during this time the teacher must remain patient and calm.

Effective methods of punishment, that do not include physical pain, are available. Alternative methods may take more time to learn and initially instill in the classroom, but are just as effective as physical abuse without the pain and psychological problems. ${ }^{219}$ Educators, administrators, and society as a whole need to embrace these methods and reduce the negative messages that children are receiving in the classroom.

\section{LEGAL RECOMMENDATIONS}

As discussed above, there are many ways of instilling positive behavior in the classroom that do not involve physical punishment. These alternatives to corporal punishment are at the discretion of individual teachers or school districts. This choice could be eliminated through statutes specifically designed to prevent physical punishment of children. If a government chooses to place an explicit ban on corporal punishment or place restriction on its use, then those policies should be strictly enforced. Disregard of the law becomes frequent when violators are not punished for their wrong.

In ratifying the Convention on the Rights of the Child, nations made the promise to uphold the safeguards in the Convention. One of these promises includes taking all measures, legal and social, to protect children from all forms of physical punishment. ${ }^{220}$ Nations that have only placed restrictions on corporal punishment, such as Kenya, have not followed through with their promises. Allowing any type of corporal punishment violates the Convention along with other human rights instruments. Therefore, such nations that have simply placed restrictions on its use should enact an explicit ban on the use of corporal punishment.

Enacting laws on corporal punishment can be very effective. It announces to the public that corporal punishment is against the policies and morals of society. "Law has an educative effect because it crystallizes and

218. See id. at 167.

219. See Corporal Punishment in Schools, supra note 17. A variety of nonviolent disciplinary techniques can be taught and utilized. See id. These techniques may be powerful and compelling in changing unacceptable behavior. See id.

220. See Convention, supra note 50, art. 19. 
makes visible in an impressive way, at the level of governmental authority, those norms that constitute a society's priorities and aspirations."221

There is much that can be done at many different levels to advocate the ban of corporal punishment. ${ }^{222}$ "Banning corporal punishment at the local level has evolved from various effective strategies, such as civil suits against local schools using corporal punishment, promotion of publicity about such schools, and comparing the computerized corporal punishment rates of some schools."223 Individuals can join various groups to evaluate their local and state views on physical punishment of children. ${ }^{224}$ The government can encourage school authorities to implement support programs to educate parents, teachers, and society at large about the harm of corporal punishment and the existence of effective alternatives. ${ }^{225}$

Governments all over the world, especially those that have ratified the Convention on the Rights of the Child, need to clarify their position on the use of corporal punishment. ${ }^{226}$ Until new regulations are adopted, parents and students should be educated about their rights under existing laws and regulations. ${ }^{227}$ Local education agencies can establish independent complaint boards to investigate individual complaints and take all appropriate and immediate disciplinary action against accused teachers found to have violated the regulations. ${ }^{228}$

\section{CONCLUSION}

Corporal punishment has a long history in many countries around the world. With this in mind, the road to instilling alternatives has been long and difficult, despite the powerful alternatives that are available. Teachers need the support of parents, administrators, and society in general to defeat the theory that without the fear of pain, a child will not develop intellectually or behaviorally.

Elimination of corporal punishment has not been easy because there is no common agreement as to the benefits or problems related to such punishment. Some teachers still depend on harsh forms of punishment to solve difficult behavioral problems.

The purpose of children's education, as posed by the Convention on the Rights of the Child, should be the development of respect for human rights

221. Bitensky, supra note 99 , at 230.

222. See Corporal Punishment in Schools, supra note 17.

223. Id.

224. See id.

225. See Spare the Child, supra note 7.

226. See id. In ratifying the Convention on the Rights of the Child, states' parties promised to uphold the protection of children against inhuman, degrading treatment or punishment. See Convention, supra note 50.

227. See Spare the Child, supra note 7.

228. See id. 
and fundamental freedoms. ${ }^{229}$ Many nations throughout the world have recognized that corporal punishment in schools violates the provisions on the Rights of the Child, and constitutes cruel, inhuman treatment. ${ }^{230}$ All governments need to take strong action to uphold the promises in the Convention to eliminate corporal punishment in schools.

Angela Bartman*

* Indiana University School of Law - Indianapolis, J.D. anticipated May 2003. 
